\title{
Deportations, the Spreading of Dissent and the Development of Democracy
}

\author{
The Confino on Ponza and Ventotene during Italian Fascism and its Political \\ Aftermath
}

\author{
Francesca Falk \\ Universite de Fribourg, Switzerland \\ Francesca.Falk@unifr.ch
}

\begin{abstract}
Instead of preventing protest, deportations on political grounds could - under certain circumstances - help to spread dissent. Accordingly, the spaces deportees were sent became fertile ground for new coalitions. Analysing such spaces furthers our understanding of how resistance may be contained, dispersed and re-constituted. The main part of this article focuses on deportations to the Pontine Islands of Ponza and Ventotene under Italian Fascism. Under such conditions, new political ideas were elaborated. The genesis of the Ventotene Manifesto will be considered as a starting point for a genealogy that opens up alternative trajectories of development for another European Union and, indeed, for today's understanding of democracy. If, today, Europe closes its borders, it destroys the idea behind such a vision of unification. Therefore, it is urgently necessary not only to recall the genesis of this manifesto, but also the authors' experience of being refugees.
\end{abstract}

\section{Keywords}

Deportation - Dissent - Resistance - Alliances - New Political Ideas - Ventotene Manifesto - European Union - Refugees

This article shows how political resistance was contained, dispersed and reconstituted in its dispersal. Political protests attempt to open up the field of 
the political. They can create a space for changes that would not be possible under the prevailing political system. ${ }^{1}$ Deportations on political grounds, by contrast, attempt to exclude both rebellious people and inopportune topics from the space of domestic debate. However, even though dissent and deportation may seem to be inherently opposed to each other, this article makes a case for conceptualising dissent and deportations as processes that are - at least at certain moments - inextricably interwoven in complex ways. The aim of this article is thus to propose a new line of research that the present article only begins to explore.

Today, there is a growing literature on anti-deportation activism. However, this literature does not focus on political deportations per se, but rather on how the fight against contemporary deportations might have produced new forms of protest and movement building. ${ }^{2}$ At the same time, a substantial body of historical work exists on deportation events enacted in the wake of political protest, as happened after the fall of the Paris Commune. More than 4,200 members of the Paris Commune were sent to New Caledonia in the southwest Pacific Ocean. Their arrival coincided with transports of political prisoners from Algeria who had taken part in the 1870-1871 Kabyle uprising against French rule. During an uprising of the local population in 1878 , almost all communards (except Louise Michel and some of her friends, who are discussed later) and deported Algerians were however on the side of the French administration. After their defeat, some of the rebels from the uprising of 1878 were in turn deported from New Caledonia to Chiapas. Reservations were created, which isolated the local population. Deportation did not stop political activism, although in this case, the political deportees from France and Algeria became willing collaborators in the eradication of the indigenous population. ${ }^{3}$

1 Judith Butler, Notes toward a performative theory of assembly (Cambridge, MA 2015).

2 Peter Nyers, 'Abject cosmopolitanism: the politics of protection in the anti-deportation movement', in: Nicholas De Genova and Nathalie Peutz (eds), The deporation regime. Sovereignty, space and the freedom of movement (Durham, London 2010) 413-442; Sieglinde Rosenberger and Jakob Winkler, 'Anti-Abschiebungsproteste: Mit Empathie gegen die Exklusion', in: Ilker Ataç and Sieglinde Rosenberger (eds), Politik der Inklusion und Exklusion (Göttingen 2012) 111-134; Lisa Doppler, "A Feeling of doing the right thing”. Forming a successful alliance against Dublin-deportations', Movements. Journal für kritische Migrations- und Grenzregimeforschung 1:2 (2015), http://movements-journal.org/issues/o2.kaempfe/12.doppler--successful-alliance-against-dublin-deportations.html, 4.5.2017.

3 See for example Jean Baronnet and Jean Chalou, Communards en Nouvelle-Calédonie. Histoire de la déportation (Paris 1987); Mehdi Lallaoui, Algériens du Pacifique (Alger 1994); Alice Bullard, Exile to paradise. Savagery and civilization in Paris and the South Pacific, 17901900 (Cambridge 2000); Louis-José Barbançon, L’Archipel des forçats. Histoire du bagne de 
It is appropriate to adopt a History from below approach, but in writing a history of deportation and the spreading of dissent, it is not easy to carry out in terms of availability of sources. ${ }^{4}$ For this study, deportations on political grounds to the Pontine Islands of Ponza and Ventotene during Italian Fascism were chosen because the sources allows us to address the question of how resistance was re-constituted in its very dispersal in an emblematic manner. Micro-historical analysis thereby promises unprecedented insight into the relation between deportations and the spreading of dissent and how new alliances were established between the deportees from different territories, as well as with the local population. In order to tackle these questions, my archival research - which was predominantly at the Archivio Centrale dello Stato in Rome $^{5}$ - focused on two types of sources: documents produced by the different authorities on the confino and the personal dossiers of the deportees. ${ }^{6}$

To contrast the documents produced by the state with the perspective of the local population, I interviewed people who had experienced the confino on Ponza (Adele Conte) or its aftermath (Silverio Lamonica, Vilma Lanfranconi Vitiello, Assunta Scarpati). Furthermore, I spoke with Enrica Canepa, whose mother Maria Vitiello had in 1931 married the deportee Giovanni Battista (Gianbattista) Canepa in Ponza. So far, no in-depth research has been carried out into the consequences and effects of such marriages. The case of Maria Vitiello and Gianbattista Canepa may illustrate the potential insights to be gained from such an approach. Whereas Maria's husband (like several other ex-confinati) published books and articles after the war about his experiences as a leading partisan, ${ }^{7}$ Maria left only a few, brief testimonies. None of the local island women who married detainees has, to my knowledge, published a detailed account of her experiences. At the Società Economica di Chiavari

Nouvelle-Calédonie (1863-1931) (Paris 2003); Mélica Ouennoughi, Algériens et Maghrebins en Nouvelle-Calédonie, de 1864 à nos jours (Alger 2008).

4 For instance, whereas there are copious sources concerning the Communards, it is much more difficult to trace the voices of the Algerians, and this applies even more to the deported local population from New Caledonia.

5 I also consulted the Archivio di Stato di Latina, but my research there did not bring to the fore any additional information of importance for the questions addressed in this article.

6 If there exists an entry in the database Casellario Politico Centrale (central register of persons considered dangerous to public order and security), it can also be accessed online: http://151.12.58.148:808o/CPC/\# (1.9.2017).

7 Giovan Battista Canepa, Le Cronache di una vita (Genova 1983); Giovan Battista Canepa, 'Una testimonianza', in: Gino Amato (ed), Il confino politico a Lipari (Marina di Patti 1990) 103-106; Giorgio Getto Viarengo, Marzo e la Cichero. Documenti e memorie (2006); Giovanni Battista (Marzo) Canepa, La Repubblica di Torriglia (2009). 
there is, however, the testimony of Maria explaining from her perspective how she became a partisan. More information on Maria's involvement in the Italian resistance was provided by her daughter. The political engagement of this family represents an impressive case study on how political resistance was reconstituted in its very dispersal. In addition to the sources mentioned, I relied, for this part of the article, on the growing literature on the confino ${ }^{8}$ as well as on Silverio Corvisieri's books on the history of Ponza. ${ }^{9}$

In the last part of this article, I will discuss how new political ideas were elaborated under the condition of the confino. In this context, the genesis of the Ventotene Manifesto is considered as a starting point for a genealogy that opens up potential trajectories of development for another European Union and, indeed, today's understanding of democracy. If, today, Europe closes its borders, it destroys the very idea behind such a vision of unification. Therefore, it is necessary not only to recall the genesis of this manifesto, but also the experience of flight of its author. By drawing on sources from the Swiss Federal Archives and the State Archives of the Canton of Ticino, I make visible the refugee background of these emblematic figures of European unification, thereby raising the question of what this might mean for our present situation.

Political Deportations and the Spreading of Dissent

Deportations after political protests and dissent have occurred in different places and periods. However, it is with the protest movements in the late eighteenth and nineteenth century that we can observe a truly transnational circulation of strategies of repression with respect to deportations. In this

8 Celso Ghini and Adriano Dal Pont, Gli antifascisti al confino. Storie di uomini contro la dittatura (Roma 1971); Alessandra Gissi, 'Un percorso a ritroso: le donne al confino politico', Italia contemporanea. Istituto nazionale per la storia del movimento di liberazione in Italia 226 (2002) 31-59; Paolo Borruso, L'Africa al confino. La deportazione etiopica in Italia, 1937-39 (Manduria 2003); Alessandra Pagano, Il confino politico a Lipari 1926-1933 (Milano 2003); Marco Lenci, Allinferno e ritorno. Storie di deportati tra Italia ed Eritrea in epoca coloniale (Pisa 2004); Carlo Spartaco Capogreco, I campi del Duce. L'internamento civile nell'Italia fascista (1940-1943) (Turin 2004); Michael R. Ebner, Ordinary violence in Mussolini's Italy (Cambridge 2011); Camilla Poesio, Il confino fascista. L'arma silenziosa del regime (Roma 2011); Filomena Gargiulo, Ventotene, isola di confino. Confinati politici e isolani sotto le leggi speciali 1926-1943 (Ventotene 2013); Ilaria Poerio, A scuola di dissenso. Storie di resistenza al confino di polizia (1926-43) (Roma 2016).

9 Silverio Corvisieri, All'isola di Ponza. Regno borbonico e Italia nella storia di un'isola (17341984) (Ponza 1985); Zi' Baldone (accade a Ponza nel Novecento) (Marina di Minturno 2003). 
context, the British deportation regime became a role model for other countries. While deportations were planned to secure tranquillity at home, they at times created a volatile 'periphery' that was ready to strike back. ${ }^{10}$ Chartism, for instance, collapsed in Britain and yet Chartist ideas flourished in places like Australia. A interesting figure in this context is the tailor William Cuffay. This son of a freed West Indian slave was elected to the Chartist National Executive in 1842 , and became famous in the spring of 1848 . As leader of the procession committee he co-organised the large demonstration for the vote held on Kennington Common on 10 April. The planned rally to bring the Chartists' petition to Parliament was, however, called off at the last moment by the Chartist leaders, a decision that Cuffay openly criticised. In Cuffay's speeches, a consistent theme was present: 'the need if necessary for the Chartists to employ physical force'. It was in this context that Cuffay was arrested on charges of armed conspiracy. After sentencing, Cuffay was transported to Tasmania (then Van Diemen's Land). Cuffay's deportation did not stop his political activism however. Over the next twenty years, he became a famous figure in some of the most important political struggles in Australian history. Interestingly, Tasmania was also a deportation island for Maori insurrectionists. It is not clear if there were contacts between the political prisoners deported from Great Britain and Ireland and deported Tasmanian Aborigines and Maori, but authorities were clearly aware of the potential for intersectional alliances and tried hard to prevent them. ${ }^{11}$ Protest was not simply imported, the political struggle changed in the new setting. What happened in Italy with regard to political deportations

$10 \quad$ Miles Taylor, 'The 1848 revolutions and the British Empire', Past and Present 166:1 (2000) 146-180, 180.

11 Helen Hughes, 'The eight hour day and the development of the labour movement in Victoria in the Eighteenfifties', Historical Studies: Australia and New Zealand 9:36 (1961) 396-412; Asa Briggs, 'Chartists in Tasmania: A note', Bulletin of the Society for the Study of Labour History 3 (1961) 4-8; George F. E. Rudé, Protest and punishment. The story of the social and political protesters transported to Australia, 1788-1868 (Oxford 1978); Norbert J. Gossman, 'William Cuffay: London's black chartist', Phylon 44:1 (1983) 56-65; Annette Betheras, William Cuffay: 'black' London chartist and Tasmanian radical. Honours thesis (University of Queensland's institutional digital repository 1993); Marian Sawer, 'Pacemakers for the world?', in: Marian Sawer (ed), Elections: Full, free \& fair (Annandale 2001) 1-27 2; Mark McKenna, "Building "a closet of prayer" in the new world: The story of the "Australian ballot", in: Marian Sawer (ed), Elections: Full, free \& fair (Annandale 2001) 45-62; Keith Flett, 'William Cuffay: black chartist \& Londoner' (2011), kmflett.wordpress.com/2011/12/26/william-cuffay-black-chartist-londoner, 26.11.2015; Mark Gregory, 'William Cuffay in Tasmania', Tasmanian Historical Research Association. Papers and Proceedings 58:1 (2011) 61-77; Martin Hoyles, William Cuffay. The life and times of a Chartist leader (Hertford 2013). 
under the Fascist regime is therefore, as we will see, 'both specific to and representative of a larger phenomenon. ${ }^{12}$

Under the government of Mussolini, deportations were widely practiced as a means of political and social repression and the so-called confino were to become a permanent institution..$^{13}$ It was in 1926 that special laws were introduced allowing deportation as a kind of preventive measure without the necessity of a proper trial. ${ }^{14}$ Of all the islands used for the confino under the fascists, ${ }^{15}$ Ponza and Ventotene were the regime's longest-serving spaces of deportation. More than 4,000 confinati were in these years detained on those two small islands. ${ }^{16}$ The Ponza 'colony' opened in $1928 .{ }^{17}$ It closed in $1939^{18}$ and the most 'dangerous' deportees were then transferred to nearby Ventotene, ${ }^{19}$ henceforth Italy's primary political colony, until its closure in September $1943 \cdot{ }^{20}$

12 Michel Wieviorka, 'Case studies: history or sociology?', in: Charles C. Ragin and Howard S. Becker (eds), What is a case? Exploring the foundations of social inquiry (Cambridge 2000) 159-172, 170 .

13 However, various governments on the peninsula had deported prisoners to the nearby island. According to Garfinkel, a system of police-administered deportations was in fact used in most of the Restoration autocracies and then employed again by the liberal government in 1863. This served 'as an important blueprint for Mussolini's confino di polizia.' Paul Garfinkel, 'Forced residence in liberal Italy: A pre-history, 1815-65', Journal of Modern Italian Studies 16:1 (2011) 37-58, 37.

14 Pagano, Il confino politico; Poesio, Il confino fascista; Capogreco, I campi del duce. L'internamento civile nell'Italia fascista (1940-1943).

15 The confino was not limited to the islands, and political opponents were also deported to other supposedly isolated places, such as little villages in the mountains.

16 Federico Longo and Andrea Managò, 'Tutti gli uomini e le donne che il duce mandò al confino', Il Venerdi di la Repubblica (2012), www.repubblica.it/mobile-rep/venerdi/2012/07/20/ news/tutti_gli_uomini_e_le_donne_che_il_duce_mand_al_confino-39283931 (20.4.2014).

17 Even in ancient times, as well as during the Bourbon dynasty, Ponza had been used as place of banishment. In the nineteenth century, delinquents, political opponents as well as war prisoners were deported to this island, such as the $45^{\circ}$ Libyans, for instance, in 1911/1912. Corvisieri, Zi' Baldone (accade a Ponza nel Novecento) 28.

18 A concentration camp was in use after 1942, mostly for prisoners from Eastern Europe.

19 Adele Conte, who was born in 1924 and is one of the last inhabitants of Ponza who is able and willing to speak about her memories of the confino, told me that as a fifteen-year-old girl she felt very melancholic about this closing, even if she had never talked to the confnati. In her view, the confino had brought many cultivated people to Ponza and its closure signified less life on the island. Personal communication Adele Comte 21 September 2016. After his overthrow in 1943, Mussolini was detained on Ponza for ten days. 
Today, the fascist confino have sometimes been referred to as 'holidays' by Italian right-wing politicians ${ }^{21}$ For this reason, it must be emphasised that the aim of this article is not deny the repressive purpose of deportations on political grounds in preventing political protest, or to belittle its potentially devastating effects on individual lives and, indeed, entire communities. Nevertheless, deportations may also have unintended effects that go beyond mere repression. Consequently, it is important to emphasise that being interested in resistance practices and the forging of new alliances does not mean neglecting the violence inherent in the fascist deportation regime. As Ebner writes: 'Although the regime did not intend for detainees to die, the experience killed many of them and left many others gravely and chronically ill, often due to the negligence of politically vindictive officials.'. ${ }^{22}$ Some forms of harassment were especially absurd. For example, the fascist soldiers sometimes cut out photos of important political personalities from newspapers and magazines and scattered them on the floor at the entrance to the confinatis' barracks. When a deportee accidentally stepped on one of these pictures, he was arrested for insulting the person in question. ${ }^{23}$ Likewise, the soldiers carried calendars in which all the holidays of different political parties were highlighted. Anyone suspected of celebrating such a holiday (e.g. anyone who happened to wear elegant clothes or to eat better meals than usual on a 'suspect' day) was similarly punished. ${ }^{24}$ Some female deportees, moreover, were imprisoned for months for entering the male barracks or for visiting the confinatis' library situated there. ${ }^{25}$ The local population was also the victim of fascist violence. An extreme example was reported from 1932, when twelve-year-old Salvatore Scotti was killed in Ponza by a fascist soldier apparently for refusing to bring the soldier grapes, ${ }^{26}$ or in 1935, when women married to deportees who protested against the mass arrest of confinati were beaten and most of them were expelled from the island. ${ }^{27}$

Even in such situations of violent coercion, however, it is still possible to identify some space for agency. For instance, even the most meticulous regime

21 Silverio Corvisieri, La villeggiatura di Mussolini. Il confino da Bocchini a Berlusconi (Mailand 2004) 20.

22 Ebner, Ordinary violence in Mussolini's Italy, 137.

23 Poesio, Il confino fascista, 77.

24 Corvisieri, All'isola di Ponza. Regno borbonico e Italia nella storia di un'isola (1734-1984) 298.

25 Silvia Vecchini, Una fonte sul confino: Il fondo Betti-Giaccaglia. Tesi di laurea in archivistica (Università di Bologna 2009/2010) 36 .

26 Corvisieri, All'isola di Ponza. Regno borbonico e Italia nella storia di un'isola (1734-1984) 277.

27 Archivio Centrale dello Stato in Rome (ACS), Elenco delle mogli di confinati politici a Ponza che hanno protestato per l'arresto dei rispetivi mariti, in seguito all'agitazione per l'applicazione di una nuova ordinanza. M.I. DgPs. AAGG, Confino Politico, Busta Nr. 17. 
of checks imposed on the confinati, their families, and the local population could not prevent secret messages being sent to the political parties with which the deportees were affiliated. Checks were successfully circumvented, for example, by deportees who used seemingly harmless spelling mistakes as a secret code. ${ }^{28}$ And even though Ponza is a small island, there were simply too many people to be kept under constant surveillance. For example, in the summer of 1939, 1,200 fishermen left Ponza to fish for lobster, in no fewer than 250 different boats. Traffic between the island and dozens of Italian, French, Tunisian and Dalmatian harbours was unceasing, thus enabling underground communication. ${ }^{29}$ Furthermore, various forms of resistance practices were possible. A particularly athletic deportee, whose guards had been ordered to follow him everywhere, used to spend his days running and thus presented a rather tiring challenge. ${ }^{30}$

The aim of the confino was to isolate dangerous militants. However, deportees remember their stay as a veritable university course in opposition and as an academy of resistance. ${ }^{31}$ These places of confinement thus literally became spaces of communication, fertile ground for new coalitions and contact zones where deportees of different geographical, political and class origins became acquainted with one another and where new political ideas were developed. ${ }^{32}$ In a way, small islands like Ponza and Ventotene were, in those years, incubators for anti-Fascism, as Paris had been for anti-imperialism between the wars. ${ }^{33}$

Particular attention ought to be paid to processes of exchange that took place between different groups of deportees, for example between Italian political opponents to the regime, fascists soldiers, as well as fascists fallen into disgrace, and the colonial and Slavic confinati. In fact, there were some cases in which confinati converted fascist soldiers. A deportee describes how some of these young men had taken on their job because they had not found any other

28 Gargiulo, Ventotene, isola di confino, 140.

29 Corvisieri, All'isola di Ponza, 314.

30 Giovanni Domaschi, Le mie prigioni e le mie evasioni. Memorie di un anarchico veronese dal carcere e dal confino fascista (Verona 2007) 98.

31 Alberto Jacometti, Ventotene 31-39; Poerio, A scuola di dissenso. Storie di resistenza al confino di polizia (1926-43).

32 Giorgio Amendola, Un'isola (Milano 1980) 185.

33 Michael Goebel, "The capital of the men without a country": migrants and anticolonialism in interwar Paris', American Historical Review 121:5 (2016) 1444-1467, 1458. See also from the same author Anti-imperial metropolis. Interwar Paris and the seeds of third-world nationalism (New York 2015). 
employment. ${ }^{34}$ In such circumstances, political propaganda from the confinati could be effective. The same deportee mentions two former watchmen who were among the best behaved in Ponza and who later participated in the Italian resistance and became members of the Communist Party. Interesting is also the case of the fascist Chilanti, who was deported to Lipari, where he too eventually became a communist. After Mussolini's fall, he joined the communist organisation Bandiera Rossa, which played a crucial role in the Roman resistance. ${ }^{35}$ Instead of being places of quarantine, these islands thus became centres of 'antifascist infection'. ${ }^{36}$ For instance, many of the deported Albanians became communists and, upon being released, acted as front-runners of the rising resistance movement. Later, they became leaders of the new Albanian state. ${ }^{37}$

Moreover, the small islands involved in such historical situations experienced important processes of change, for example when it comes to electrification, private lessons given by some of the detainees, or the establishment of libraries and sports facilities like a boxing ring by some of the confinati. ${ }^{38}$ Whenever possible, the confinati organised education programmes and systematic and specialised lectures were given in, for example, history, economics, finance, statistics, and languages - and fighters from the international brigades in Spain gave lessons in military techniques which later proved important for the partisans. ${ }^{39}$

In this context, it is also important to investigate the interactions between such groups and the local population and their - possibly shared - resistance practices. Within only a few years, more than 25 marriages had taken place between local women and the confinati on Ponza. ${ }^{40} \mathrm{In} 1937$, the inspector general for public security came to see a great danger in such relationships, and he tried to explain the problem to the Chief of Police in Rome:

\footnotetext{
34 Ghini and Dal Pont, Gli antifascisti al confino, 83.

35 Corvisieri, La villeggiatura di Mussolini. Il confino da Bocchini a Berlusconi, 71.

36 Altiero Spinelli, Come ho tenato di diventare saggio (Bologna 1999) 241.

37 Ghini and Dal Pont, Gli antifascisti al Confino, 141.

38 Pagano, Il confino politico, 184,193. The latter were in fact also very popular with the fascist militia. In his political autobiography, the confinato Giovanni Battista Canepa mentions that, one day, many of the fascist soldiers reported to duty with black eyes, which led the commander of the colony to forbid boxing. Canepa, Le cronache di una vita 113 .

39 Filomena Gargiulo, 'Com'era il confino a Ventotene', (2013), www.anpi.it/articoli/1045/ comera-il-confino-a-ventotene (17.11.2015).

40 Corvisieri, Zi' Baldone (accade a Ponza nel Novecento) 63. The commissioner Giovanni Pellicciotti speaks of forty marriages in ten years. See Annibale Folchi, La persecuzione politica a Littoria (Formia 2005) 309.
} 
Since this state of affairs creates an environment of friendship and protection around the confined and thereby affects the surveillance measures, above all in regard to clandestine correspondence, it appears necessary to proceed with the gradual removal of the listed married confinati and those who will be discovered in the future to keep loving relationships with local women. ${ }^{41}$

As we have seen, no in-depth research has been carried out into the consequences and effects of such marriages. The case of Maria Vitiello and Gianbattista Canepa exemplifies the insights to be gained from such research.

In 1926, Gianbattista had been condemned to five years of confino on the island of Lipari. ${ }^{42}$ Because of an unsuccessful attempt to flee, he was transferred to Ponza in 1928. There, he met the 19-year-old Maria, whose father, a socialist, owned a pharmacy and had rented a room to some confinati (the kind of housing conditions the deportees were allocated depended on the sentence that had been passed and on the specific time and place of their confinement). Such spaces - like this pharmacy back-room - were useful for carrying out illegal activities and in this case it offered several possible escape routes in case of a sudden raid by soldiers. ${ }^{43}$

Maria and Gianbattista eventually became a couple. ${ }^{44}$ However, they were forced to interrupt their relationship when Gianbattista was sent to prison in Naples in the summer of 1930, where he served a two-year sentence for, among other things, his attempted flight from Lipari. ${ }^{45}$ When he was released from prison and returned to Ponza, the couple renewed their relationship and eventually married in 1931. Gianbattista reports that Maria's family did not attend the ceremony because the wedding took place in a civil registry office and not

41 ACs, Ponza = Colonia di confino politico, M.I. Dg Ps. AAG G, Confino Politico, Busta Nr. 13, my translation. Marriages between male confinati and local women occurred also in Lipari, 36 cases are reported. Pagano, Il confino politico 172. In Ventotene, such contacts were more difficult and only one marriage was celebrated. Gargiulo, Ventotene, isola di confino 221.

42 Simonetta Carolini and Adriano Dal Pont, L'Italia al confino. Le ordinanze di assegnazione al confino emesse dalle commissioni provinciali dal novembre 1926 al luglio 1943 (Milano 1983) 753 .

43 Corvisieri, Zi' Baldone (accade a Ponza nel Novecento) 63.

44 Giorgio Getto Viarengo, 'Giovanni Battista Canepa "Marzo", in: Giorgio Getto Viarengo (ed), Il secolo breve nel Tigullio (Chiavari 2013) 9-16.

45 ACs, Alto Commissariato Napoli 12 giugno 1930 al Ministero dell'Interno Direz. Gener. Della Pubblica Sicurezza Servizio schedario, Casellario Politico Centrale, busta Nr. 1001. 
in a church. ${ }^{46}$ Such occurrences had an impact on local wedding customs, as marriages between local women and confinati were usually not celebrated in churches. ${ }^{47}$ Even such forms of forced migration have thus contributed to the emergence of new social practices. ${ }^{48}$

After Gianbattista's release in $1932,{ }^{49}$ Maria and their daughter Enrica, who had been born in 1931, followed him to Chiavari in 1933 and, in 1935, to Turin. In 1937, Gianbattista joined the anti-Franco resistance in Spain where he was wounded after a short time. He left for France to receive treatment, where he was joined by Maria and their daughter Enrica in $1938 .{ }^{\circ}$ Enrica and Maria were both interrogated separately by Swiss border guards - they crossed the border near Tirano - but were eventually allowed to continue their journey. Because of the dangers of this difficult passage, Maria had left her baby boy Enzo, who at the time was only six months old, in the care of her mother.

In France, Gianbattista was again imprisoned several times. In the meantime, Maria worked, for example as a kitchen helper in a restaurant in Saint Tropez..$^{51}$ The experience of the 'Popular Front' in France and its aftermath further politicised Maria. ${ }^{52}$ When Italy entered the war in 1940, Maria and Enrica joined the last convoy going from France to Italy and returned to their homeland. ${ }^{33}$ There, Maria, together with Enrica, reunited with Maria's mother and little Enzo, who by then called his aunt Rita his mother. ${ }^{54}$ Maria and her mother wanted to go to Ponza together with the two children, but as no ship was available they had to wait in the town of Sorrento near Naples. Here, both

46 Canepa, Le cronache di una vita 126.

47 Pagano, Il confino politico, 174.

48 Whether or not this change left lasting traces on Ponza would need to be examined more closely. I discuss the relation between migration (understood in a broad sense, including both forms of internal as well as international mobility) and social change in my recently published open access book Francesca Falk, Gender Innovation and Migration in Switzerland. Palgrave Studies in Migration History (Cham 2019).

49 ACs, Alto Commissariato Napoli 2 Agosto 1932 al Ministero dell' Interno Direz. Gener. Della Pubblica Sicurezza Servizio schedario, Casellario Politico Centrale, busta Nr. 1001.

5o According to Enrica, Maria suffered from severe frostbite on her legs after crossing the Alps on foot. Personal communication Enrica Canepa 5 September 2014.

51 Canepa, Le cronache di una vita, 163.

$5^{2}$ Personal communication Enrica Canepa 5 September 2014.

53 Canepa, Le cronache di una vita, 166.

54 Because of a recently introduced amnesty law, Maria did not have to go to prison for having left Italy illegally. 
children were infected with typhus, a disease to which the little boy eventually succumbed. ${ }^{55}$

In 1943, after the armistice with the Allies proclaimed by Marshal Badoglio, Gianbattista followed Maria and Enrica to Italy and, together, they proceeded to Liguria. In the following years, each member of the family played an important role in the Italian resistance: Gianbattista, who had been decorated in World War I, led a group of partisans; Maria provided food, information and health care; and their young daughter Enrica transmitted secret messages. There is a first-hand-account by Maria, probably written at the end of 1970, describing from her perspective a spectacular flight in 1943 that allowed her to avoid arrest and deportation. ${ }^{56}$

Subsequently, Maria participated at the struggle of one of the most famous partisan formations - a group that, nearly two years later, successfully fought for the liberation of Genoa. There, Maria is said to be the first female partisan. ${ }^{57}$ In 1995 , a poem was dedicated to her by Giorgio Gibelli, himself a former partisan. It ends with the words: 'and it's not over yet over [the resistance], it can't finish like that. ${ }^{\prime 58}$

\section{The confino and its Aftermath}

In its particulars, the story of Maria Vitiello is unique. However, Maria's sister Elena also married a famous ex-confinato, Vincenzo Baldazzi. Taking into account these facts, it does not appear to be a coincidence that Maria and Elena were the sisters of Mario Vitiello, the first left-wing mayor of Ponza (1975-1980). Mario Vitiello, in turn, played a decisive role in closing an environmentally

55 After his death, Maria fell into a severe depression. Personal communication Enrica Canepa 5 September 2014.

56 Società Economica di Chiavari, Testimonianza di Maria Vitiello Canepa di un episodio della resistenza, fasc. di 2 cc., doc. n. 436, Fondo G.B. Canepa 'Marzo'. See also Maria Vitiello, 'Testimonianza di Maria Vitiello', in: Nicolò Bonacasa and Remo Sensoni (eds), Vite da compagni. Dall' antifascismo al compromesso storico (Roma 1998) 6o-61, 130-132.

57 Annalisa Rimassa, 'La baby partigiana: "In spalla di notte per nascondermi ai fascisti", Secolo XIX (2016), http://www.ilsecoloxix.it/p/cultura/2016/04/19/ASqagJQC-fascisti_nascondermi_partigiana.shtml (26.9.2016). See also Conte Rosanna, 'Il ricordo di Maria Vitiello nelle scuole di Genova', Ponza racconta (2016), http://www.ponzaracconta.it/2016/05/16/ il-ricordo-di-maria-vitiello-nelle-scuole-di-genova/ (26.9.2016).

$5^{8}$ Giorgio Gibelli, 'Maria', La Repubblica di Torriglia (Genova 1995) 165-166 166. Translation by the author. 
detrimental bentonite mine. ${ }^{59}$ Moreover, his government built various schools and streets, expanded public housing and extended the sewage system. ${ }^{60} \mathrm{He}$ also organised a meeting with Sandro Pertini, ex-confinato who served as President of the Italian Republic from 1978 to 1985 . According to Silverio Lamonica, who was then the vice mayor, the supply of the Italian islands by cistern ships improved more quickly in these years because personal contact with Pertini had been established while he was confined on the island and because Pertini himself had experienced the effects of water scarcity when he had been detained there. ${ }^{61}$

The confino and its aftermath left many marks on the confined, on the islands and their inhabitants - and on the resistance movement throughout Europe. ${ }^{62}$ Without confino, there would probably not have been a partisan movement of this kind. ${ }^{63}$ Broader alliances for fighting Fascism could be formed and the motivation and knowledge needed for resistance (such as specific military techniques) could be transmitted. Such developments were thus marked by political learning and innovation. ${ }^{64}$ In this context, a remarkable example is to be found in 1937, when the Nazi salute was introduced on all Italian deportations islands. There was fierce opposition to this new order from the beginning, especially on the island of Tremiti, and as a result many deportees were sentenced in court - events that were reported both by Radio Moscow and the foreign press. ${ }^{65}$

59 Corvisieri, Zi' Baldone (accade a Ponza nel Novecento) 299, 317.

60 Rosanna Conte, 'Don Mario: il sindaco Vitiello', Ponza racconta (2013), http://www .ponzaracconta.it/2013/10/3o/don-mario-il-sindaco-vitiello-2 (26.9.2016).

61 Personal communication Silverio Lamonica 18 September 2016.

62 There are still many more exciting aspects to be studied in this context. For instance, Assunta Scarpati, whose two aunts Ida and Libera both married a confinato (Fantoni Armando and Vittorio Zovich, respectively), stated that the stimulus provided by these relatives was very important for her being able to attend high school (situated on the mainland). Personal communication Assunta Scarpati 11 July 2014.

63 Ghini and Dal Pont, Gli Antifascisti al, Confino 217.

64 Rebecca Kolins Givan, M. Robert Kenneth, and Sarah A. Soule, 'Introduction', in: Rebecca Kolins Givan, M. Robert Kenneth, and Sarah A. Soule (eds), The diffusion of social movements. Actors, mechanisms, and political effects (New York 2010) 1-15, 2.

65 Gargiulo, Ventotene, isola di confino 65. Finally, the confinato Mario MammuccariBrandani wrote an essay arguing that if the deportees performed the Nazi salute in spite of their true beliefs, this would in fact constitute a degradation of this fascist symbol. This text reached Mussolini, who then decided that the confinati did not have the right to perform the Roman salute. For the then confined Jaurès Busoni, this episode recalled that of a knight who had just fallen from his horse claiming that he had wanted to dismount anyway. Jaurès Busoni, Confinati a Lipari (Mailand 1980) 47. 
One of the protagonists of this rebellion was the Eritrean Isahac Menghistu. ${ }^{66} \mathrm{He}$ had come to Italy as a student in $1928 .{ }^{67} \mathrm{In}$ an oral history interview conducted in 1991, he explained the reason for his deportation: he had openly expressed his solidarity with his compatriots when Italy invaded Ethiopia in $1935 .{ }^{68}$ Isahac's life at the confino was especially hard, as the fascist soldiers gave free rein to their feelings of racial superiority. ${ }^{69} \mathrm{He}$ was finally brought to Ventotene in 1938 , where he became a friend of Sandro Pertini. ${ }^{70}$ In the literature on Isahac's life, the influence of the Italian confinati on his political 'maturation' is highlighted. ${ }^{71}$ Quite tellingly, however, such secondary sources do not ask how the Italian confinati were, in their turn, influenced by their encounter with Isahac and his political views, for instance with regard to the question of colonialism and anti-colonial resistance. Here too, an interesting field of research is opening up.

\section{4} The Development and Spread of New Political Ideas

Under the circumstances of the confino, new political ideas were developed. What has been noticed with regard to the refugees' significant influence on the development of science in the US during and after the Second World War, is plausible in other contexts as well. It has been shown that the pressures of forced migration could in fact encourage new ways of thinking. Because of the shortage of US jobs for refugee physicists, these scientists had to turn their skills into novel fields like biology, thereby inventing a new approach to biochemistry and genetics. ${ }^{72}$ Likewise, the impact of German-speaking scholars on the humanities and social sciences in the US produced a new synthesis

66 Gargiulo, Ventotene, isola di confino, 65, 76 .

67 Lenci, All'inferno e ritorno, 49-69.

68 Irma Taddia, Autobiografie africane. Il colonialismo nelle memorie orali (Milano 1996) 67. Ras Immirù Hailè Sellassiè, commander of the Ethiopian forces and cousin of the Emperor, was also confined on Ponza from 1937 until the closing of the confino.

69 Francesco Fancello, 'Il moro Minghistu', in: Celso Ghini and Adriano dal Pont (eds), Gli antifascisti al confino (1971) 235-236.

$70 \quad$ Sandro Pertini and Vico Faggi, Sandro Pertini, sei condanne, due evasioni (Milano 1973); Marco Lenci, 'Un intellettuale eritreo spesso al "Fosso", Lettera del Centro Studi e Documentazione Isola di Ustica:17/18 (2004) 1-3.

71 Lenci, 'Un intellettuale eritreo'.

72 Mitchell Ash, 'Forced migration and scientific change after 1933', in: Roberto Scazzieri and Raffaella Simili (eds), The migration of ideas (2008) 161-178. 
between empiricism and theory. ${ }^{73}$ Similarly, in the constellation analysed here, there is a good case to be made that the influential Ventotene Manifesto (the first version was written in 1941), with its critique of nationalism and support for a European federation, is a product of the specific circumstances of the confino, where different oppositional groups from various nations met and where new alliances were forged, but also strict exclusions were pronounced, especially by the underground Communist Party, ${ }^{74}$ as was the case with Altiero Spinelli. He had been excluded from the Communist Party during his confino on Ponza because of his criticism of Stalin and of the Communist repression of the Anarcho-Trotskyist revolt in Barcelona. ${ }^{75}$ Moreover, Altiero Spinelli saw even the explicitly internationalist Communist Party as closely tied to the national state, among other reasons because of the envisaged nationalisation of the economy. ${ }^{76}$ As a consequence of his expulsion, Altiero Spinelli had to create a new political identity. Together with Ernesto Rossi, he wrote the Ventotene Manifesto, a text produced in close cooperation with Eugenio Colorni and Ursula Hirschmann. ${ }^{77}$ The individuals involved in editing this manifesto came from different intellectual and political orientations, but together they developed the conviction that the idea of absolute national sovereignty would

73 Laura Fermi, Illustrious immigrants. The intellectual migration from Europe 1930-41 (Chicago 1968); Donald Fleming and Bernard Bailyn, The intellectual migration. Europe and America 1930-1960 (Cambridge, Mass. 1969); Paul K. Hoch, 'Migration and the generation of new scientific ideas', Minvera 25:3 (1987) 209-237; Paul Hoch and Jennifer Platt, 'Migration and the denationalization of Science', in: Elisabeth T. Crawford, Terry Shinn and Sverket Sörlin (eds), Denationalizing Science. The contexts of international scientific practice (Dordrecht 1992) 133-152; Jennifer Platt, 'Some issues in intellectual method and approach', in: Edward Timms and Jon Hughes (eds), Intellectual migration and cultural transformation. Refugees from National Socialism in the english-speaking world (Wien 2003) 7-19; Peter Burke, Exiles and expatriates in the history of knowledge, 1500-200o (Waltham 2017).

74 Alessandro Coletti, Il governo di Ventotene. Stalinismo e lotta politica tra i dirigenti del PCI al confino (Milano 1978); Jacometti, Ventotene.

75 Amendola, Un'isola 179; Piero S. Graglia, Altiero Spinelli (Bologna 2008). Spinelli, Come ho tenato di diventare saggio 251. The visit of Matteo Renzi, Angela Merkel and François Hollande to Ventotene and the laying of a wreath on Spinelli's tomb recently ensured some media attention as well as criticism, see for instance 'Ventotene summit to chart roadmap for EU's response to Brexit vote', The Guardian (2016), https://www.theguardian.com/ world/2016/aug/21/ventotene-summit-france-italy-germany-eu-brexit-vote, (26.9.2016); Michele Smargiassi, 'Renata Colorni: "Non c’è più lo spirito di Ventotene in questa Europa egoista e divisa”, La Repubblica (20 August 2016).

76 Graglia, Altiero Spinelli 160.

77 Altiero Spinelli, 'Intervista con Altiero Spinelli', Il progetto europeo (Bologna 1985) 201-213 203-204. 
inevitably produce new wars. Therefore, only a union based on the principle of federalism was to prevent armed conflicts: 'The question which must first be resolved, and if it is not then any other progress made up to that point is mere appearance, is that of the abolition of the division of Europe into national, sovereign states. ${ }^{78}$ The aim of such a political order was to guarantee international peace and social justice. Of course, this vision was based on preexisting theories in political philosophy. What has been characterised as new is, however, that the manifesto did not want to be just a statement of principle, but an action plan. ${ }^{79}$ Why, however, the question of the refugees and migration in general is not explicitly addressed in the manifesto has, to the best of my knowledge, not yet been addressed in research - here again, there is a need to think further.

The manifesto was smuggled to the continent by Ada Rossi, Ursula Hirschmann and Fiorella and Gigliola Spinelli and circulated among the Resistance, ${ }^{80}$ as well as in Switzerland. ${ }^{81}$ The manifesto proposed a vision of European unification that aimed, inter alia, at an economic system that differed sharply from the current regime fashioned by the $\mathrm{EU}$ and its predecessor organisations. The genesis of this manifesto under the concrete conditions of the confino ${ }^{82}$ could be taken as a starting point for a genealogy that also opens up alternative trajectories of development for another European Union and, indeed, today's understanding of democracy.

78 Thismanifestoisavailableonline,seeforexamplehttp://www.cvce.eu/content/publication/ 1997/10/13/316aag6c-e7ff-4b9e-b43a-958eg6afbecc/publishable_en.pdf (1.1.2017). For the different versions, see Giulia Vassallo, 'Il Manifesto di Ventotene: premesse per un'edizione critica. Parte I. Problematiche filologiche', (2011), http://www.eurostudium.eu/rivista/ monografie/premesse\%2ol\%2oparte.pdf (1.5.2016).

79 Norberto Bobbio, 'Il federalismo nel dibattito politico e culturale della resistenza', in: Sergio Pistone (ed), L'Idea dell'unificazione europea dalla prima alla seconda guerra mondiale. Relazioni tenute al convegno di studi svoltosi presso la Fondazione Luigi Einaudi (Torino, 25-26 ottobre 1974) (Torino 1975) 221-236 221.

80 Maria Teresa Antonia Morelli, 'Ursula Hirschmann: “un'europea errante”, in: Luisa Passerini and Federica Turco (eds), Donne per l'Europa. Atti delle prime tre giornate per Ursula Hirschmann (Torino 2011) 186-198, 189; Spinelli, Come ho tenato di diventare saggio 316. Gargiulo, Ventotene, isola di confino 144; Antonella Braga and Rodolfo Vittori, Ada Rossi (Milano 2017) 54.

81 Swiss Federal Archives (SFA), dossier Rossi, Ernesto, E4320B\#1991/243\#1742.

82 Chiara Maria Pulvirenti, L'Europa e l'isola. Genesi del manifesto di Ventotene (Acireale 2009); Giorgio Braccialarghe, Nelle spire di Urlavento. Il confino di Ventotene negli anni dell'agonia del fascismo (Genova 2005 [1970]) 80-90. 
But its authors had not only lived together in Ventotene, they also experienced what it means to be a refugee. Whereas Eugenio was killed in Rome by the fascists at the end of May 1944 (just a few days before the liberation of the Italian capital), Altiero and Ernesto fled to Switzerland in September 1943. There, they wanted to explore the possibilities of political action outside of Italy and to make contacts with federalists in other countries. In the literature, it is pointed out that they were inspired by the Swiss federalist system, which they were able to study in situ. ${ }^{83}$ However, the notion that they experienced concretely what it means to be a refugee there remains understudied. For this reason, in what follows, I will reconstruct their experiences of flight and being refugees.

Altiero and Ernesto were both accompanied in exile by family members. Ernesto by his wife Ada (who followed him to Switzerland after a few days) and Altiero by his sister Fiorella. Together with Altiero and Fiorella there was also Ursula Hirschmann and her three young daughters. At that time, Ursula was still married to Eugenio Colorni, but the two had already separated from each other, and we will soon see why this will matter. ${ }^{84}$

All of 'our' refugees crossed the Swiss border illegally. ${ }^{85}$ Ernesto, the first to enter Switzerland, took a wrong turn at night, which led to a very difficult descent for his group. All of 'our' refugees engaged local smugglers to get across the border. Altiero wrote that he had paid 5,00o Lire for this service. He travelled together with Fiorella, Ursula and her daughters. ${ }^{86}$ Ada Rossi mentioned as well that she had to pay a large amount of money and that half-way there, she even had to give to the smuggler a supplement. ${ }^{87}$ According to a report published in 1946 by Antonio Bolzani - the former commander of the military

83 See for example Renata Broggini, Terra d'asilo. I rifugiati italiani in Svizzera, 1943-1945 (Bologna 1993) 325; Eluggero Pii, 'Intervento di Eluggero Pii', Quadernidell'Associazione Carlo Cattaneo. Ernesto Rossi (1897-1967): La democrazia, il Ticino, l'Europa. Atti dell'incontro:46 (1997) 19-24.

84 Piero S. Graglia, 'Colorni, Spinelli e il federalismo europeo', in: Maurizio Degl'Innocenti (ed), Eugenio Colorni dall'antifascismo all'europeismo socialista e federalista (Manduria, Bari, Roma 2010) 209-250 228.

85 This is described in a letter by Ernesto Rossi to Luigi Einaudi dating from 23 October 1943. Luigi Einaudi and Ernesto Rossi, Carteggio (1915-1961). A cura di Giovanni Busino e Stafania Martinotti Dorigo (Torino 1988) 127.

86 SFA, dossier Spinelli, Fiorella and Spinelli, Altiero, Einvernahmeprotokoll dating from 29 February 1944, E4264\#1985/196\#23303. Spinelli, Come ho tenato di diventare saggio 377-378.

87 Ada Rossi, Qualche ricordo del periodo in Svizzera (Roma 1986) 3. 
district at the southern border of Switzerland - at least 1,00o smugglers were active in Ticino. Most of the arrested smugglers were woodcutters. ${ }^{88}$ In order to avoid being arrested by Swiss border guards, many smugglers accompanied the refugees only to the border.

What were the smugglers paid for their service? As stated by Bolzani, the Comitato di liberazione nazionale paid between 100 and 200 lire for each soldier (the smugglers were able to obtain this money from the CLN by showing the signature of the trafficked soldier to this organisation, which was the main representative of the Italian resistance movement). For racially persecuted individuals, on the other hand, higher tariffs were applied: 'Almost all Jewish refugees claimed to have paid for their guidance to the border amounts ranging from five thousand to fifty thousand lire.' 89

Without a local guide, there was the danger of running into the Germans or dying in the mountains..$^{90}$ There were, however, also people who offered their help without payment. Altiero later described himself not as a refugee, but as a missionary of the federalist movement in Switzerland. ${ }^{91}$ But in January 1944 he wrote to the leader of the Ticino socialists and member of the cantonal government, Guglielmo Canevascini, that if it had not been for his intervention, he would have probably been rejected beyond the borders, in the unpleasant situation of being in an area that he did not know and that was patrolled by the Germans. ${ }^{92}$

The member of this group who was most in danger was Ursula Hirschmann. Ursula and her daughters were in fact the only ones with a Jewish family background (her husband Eugenio also came from a Jewish family). As a student in Berlin, Ursula had already participated in the anti-Fascist opposition and her political engagement continued later in France and Italy. However, it was

88 Antonio Bolzani, Oltre la rete. Episodi dei fuorusciti italiani dal 1939 al 1945 (Bellinzona 1946) 44 .

89 Oltre la rete 45, 46. Translation by the author. By comparison, in a leaflet published in Italy, according to Bolzani the Nazis claimed to pay 1800 lire for every Anglo-American prisoner delivered to the German military.

9o See for instance SFA, Englische, amerikanische und russische Kriegsgefangene die auf der Flucht in die Schweiz in den Bergen bei Brisago erforen sind, E2001D\#1000/1553\#6307.

91 Spinelli, 'Intervista con Altiero Spinelli', 207.

92 State Archives of the Canton of Ticino (АСТ), Fondo Guglielmo Canevascini, sc.82, fs. Altiero Spinelli, Letter from Altiero Spinelli to Guglielmo Canevascini from January 4 1944, quoted after Sonia Castro, 'I socialisti svizzeri e la battaglia di Spinelli nel territorio elvetico', in: Cinzia Rognoni Vercelli, Paolo G. Fontana, and Daniela Preda (eds), Altiero Spinelli, il federalismo europeo e la Resistenza (Bologna 2012) 199-216 204. See also Nelly Valsangiacomo, Storia di un leader. Vita di Guglielmo Canevascini, 1886-1965 (Lugano 2001). 
only Eugenio who was confined to Ventotene. ${ }^{93}$ She had accompanied him as his wife, and only for this reason was she able to travel and to smuggle the manifesto to the mainland. Nevertheless, in the Swiss police questionnaire, she stated under the paragraph 'previous convictions' that she had been confined alongside her husband for suspicion of anti-Fascist activity. ${ }^{94}$ Would Ursula have been recognised as a political refugee without this - as we know - not completely accurate statement? In the interrogation records drawn up by the Swiss Federal Police it was in any case indicated that her entry into Switzerland was due both to political and racial reasons, ${ }^{95}$ which could have endangered her application. The Federal Council had decided that, with the exception of deserters and political refugees, 'illegal immigrants' were to be deported to their country of origin. Refugees on grounds of race were not regarded as political refugees and it was only in July 1944 that these restrictive directives were abolished. ${ }^{96}$ These rules were, however, applied with more or less rigour by the local border police. ${ }^{97}$ In the case of our refugees, they were all accepted as political refugees and even managed to become 'liberated', i.e. they did not have to live or only for a short period in camps. ${ }^{98}$ This enabled them to continue their political project while being in Switzerland. They studied in libraries, published texts and organised meetings. ${ }^{99}$ For instance, a federalist declaration was published that had been edited together with other members of the Italian, Dutch, Yugoslav, French, Norwegian, Danish, Polish, Czechoslovakian

93 ACs, Confinati politici, fasc. pers. b. 271, Eugenio Colorni; Casellario Politico Centrale b. 1422; polizia politica, fascicoli personali, b. 320 .

94 SFA, dossier Colorni-Hirschmann, nun: Spinelli, Ursula, Fragebogen-Questionnaire, E4264\#1985/196\#31816.

95 SFA, dossier Colorni-Hirschmann, nun: Spinelli, Ursula, Einvernahmeprotokoll, E4264 \#1985/196\#31816.

96 UEK, Die Schweiz und die Flüchtlinge zur Zeit des Nationalsozialismus (Bern 1999) 197.

97 There is an ongoing discussion about the number of rejected refugees. A good overview is given in Jürg Krummenacher, 'Schweiz wies mehr Flüchtlinge ab als angenommen', Neue Zürcher Zeitung (9 June 2017); Kaspar Surber, 'Abgewiesene jüdische Flüchtlinge. Zahlenstreit ums Unfassbare', Wochenzeitung (8 June 2017).

98 The Federal Council had created the instrument of long-term internment for the accepted refugees. They were to be removed from the cities, subjected to forced labour and stringently monitored. Simon Erlanger, "Nur ein Durchgangsland". Arbeitslager und Internierungsheime für Flüchtlinge und Emigranten in der Schweiz, 1940-1949 (Zürich 2006).

99 Antonella Braga and Francesca Pozzoli, 'Il dibattito sulla federazione europea in Svizzera (1943-1945): movimenti, progetti, incontri internazionali', in: Nelly Valsangiacomo (ed), Le Alpi e la guerra. Funzioni e immagini (Lugano 2007) 79-130. 
and German resistance. ${ }^{100}$ Through contacts established in Switzerland, the document was then sent to resistance groups throughout Europe. According to Ernesto, such a result could only be obtained by operating from Switzerland. ${ }^{101}$

This scope for political action must not, however, obscure the fact that many restrictions were imposed on their daily lives. Documents from the Swiss Federal Archives and the State Archives of the Canton of Ticino show the regulatory requirements imposed on such individuals. They were not allowed to undertake any political activities or to accept any paid or unpaid work without approval. Ursula was probably particularly aware of such limitations. She was not always accommodated with her daughters and had to obtain a permit to visit her children. ${ }^{102}$ In addition, she was expecting her fourth child conceived with Altiero. As Ursula wrote to the authorities that she wanted to withdraw 624.10 Swiss Francs received from her brother (who was staying in the US) in order to be able to buy necessary items for the baby, only 250 Swiss Francs were released. ${ }^{103}$ In June, she asked again if she could withdraw 400 Swiss Francs from her account in order to cover the expenses related to the forthcoming birth and the childbed. This was not allowed:

According to article 8 of the federal council decree of 12 March 1943, the funds of a refugee are primarily liable for all public claims, for the costs of his livelihood as well as for his spouse, children, parents and siblings and are, moreover, to be put aside for further migration. ${ }^{104}$

100 Antonella Braga, Un federalista giacobino. Ernesto Rossi pioniere degli Stati Uniti d'Europa (Bologna 2007) 436.

101 Un federalista giacobino. Ernesto Rossi pioniere degli Stati Uniti d'Europa 438. For the impact of these refugees on Switzerland, see Stéphanie Prezioso, 'Les exilés antifascistes et leur impact sur la culture des pays d'accueil. Réflexion autour de l'immigration italienne', in: Alain Clavien and Nelly Valsangiacomo (eds), Les intellectuels antifascistes dans la Suisse de l'entre-deux-guerres (Lausanne 2006) 111-124; Damir Skenderovic, 'Formen und Folgen transnationalen politischen Engagements. Italienische Antifaschisten in der Zwischenkriegszeit', in: Sabine Haupt (ed), Tertium Datur! Formen und Facetten interkultureller Hybridität (2014) 135-149.

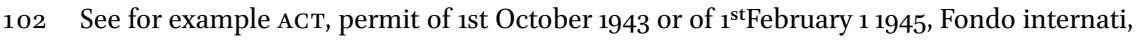
24.2 (Ursula Colorni).

103 SFA, dossier Colorni-Hirschmann, nun: Spinelli, Ursula, letter from the chief of the police department to Ursula Colorni dating from the 18 April 1944, E4264\#1985/196\#31816.

104 Translation by the author. SFA, dossier Colorni-Hirschmann, nun: Spinelli, Ursula, letter from the chief of the police department to Ursula Colorni dating from 14 June 1944, E4264\#1985/196\#31816. The money left after Ursula's departure from Switzerland (607.20 Swiss francs) was not refunded to her until 1958. SFA, dossier Colorni-Hirschmann, 
At the end of June, Ursula gave birth to her fourth daughter Diana. Just one day earlier, Altiero had written to Ernesto that he planned to return to Italy in order to join the Italian resistance. ${ }^{105}$ Altiero went back in September, ${ }^{106}$ but on 21 December he returned to Switzerland with a false passport. ${ }^{107} \mathrm{He}$ remained in Switzerland and in January 1945, Ursula and Altiero got married, despite facing great bureaucratic difficulties, as their birth certificates were not available, nor was there an official certificate of Eugenio's death. ${ }^{108}$ In the middle of February, they left Switzerland and travelled by car to liberated France. ${ }^{109}$ There, they organised and participated in a federalist conference that took place in March. In the middle of May, they returned illegally to Switzerland and then left from there for Italy in order to look for a place to stay with their daughters. ${ }^{110}$

In the meanwhile, the children had remained in Switzerland. Ursula's youngest daughter Diana was in a nursery in Geneva, Silvia (born in 1937), Renata (born in 1939) and Eva (born in 1941) were staying at a holiday and recreational home in Ascona. Their care, however, was inadequate. The older girls had become, according to Altiero, lean, hungry, dirty and sick and the baby was emotionally neglected. ${ }^{111}$ At the end of September 1945, Ursula was finally able to collect them. ${ }^{112}$ Later, she put her experience of life in the following words:

nun: Spinelli, letter from the chief of the police department to Bruno Caizzi dating from 29 January 1958, E4264\#1985/196\#31816.

105 Letter from Altiero Spinelli to Ernesto Rossi dating from 27 June 1944 quoted after Ernesto Rossi and Altiero Spinelli, "Empirico"e "Pantagruel". Per un'Europa diversa. Carteggio 19431945 a cura di Piero S. Graglia (Milano, Italy 2012) 137.

106 The return request signed by him dates from 20 September 1944. SFA, dossier Spinelli, Fiorella and Spinelli, Altiero, dichiarazione, E4264\#1985/196\#23303.

107 In the interrogation protocol, he stated that he had come back to Switzerland in order to reach France. According to him, he should have found a regular entry permit at the border. However, this permit not being there, he made a stop in Switzerland. SFA, dossier Spinelli, Fiorella and Spinelli, Altiero, Einvernahmeprotokoll dating from 26 December 1944, E4264\#1985/196\#23303.

108 Rossi and Spinelli, "Empirico" e "Pantagruel", 69.

109 Edmondo Paolini, Altiero Spinelli. Dalla lotta antifascista alla battaglia per la Federazione europea. 1920-1948: documenti e testimonianze (Bologna 1996) 464.

110 Klaus Voigt, 'Profughi e immigrati ebrei nella resistenza italiana', La Rassegna Mensile di Israel 74:1/2 (2008) 229-253, 237.

111 Spinelli, Come ho tenato di diventare saggio, 408, 413.

112 SFA, dossier Colorni-Hirschmann, nun: Spinelli, Ursula, see for example letter from contrôle de l'habitant de Genève to Croix-Rouge Suisse dating from 4 October 1945, E4264\#1985/196\#31816. 
Days ago, at a political meeting, I understood why it was so much easier for me to be European. [...] I'm not Italian although I have Italian children, I'm not German although Germany once was my homeland. And I'm not Jewish, though it was a pure coincidence that I was not arrested and then burned in one of the ovens of some extermination camp. ${ }^{113}$

Due to her knowledge and experience of what it meant to cross a border illegally and to live in exile, Ursula worked to overcome nationalism for as long as her health allowed. ${ }^{114}$

\section{$6 \quad$ Closing Considerations}

In following the traces of Maria Vitiello and Ursula Hirschmann, not only private, but also structural conditions are brought to the fore. It has been pointed out that deportations on political grounds did not always lead to the desired result, and instead of preventing protest, they helped spread it to other places. As in other circumstances of confinement, ${ }^{115}$ deportees remembered their stay as a veritable university course in opposition and as an academy of resistance. Accordingly, these spaces became fertile ground for new coalitions and contact zones where deportees of different geographical, political and class origins became acquainted with one another. Analysing how Maria Vitiello eventually became the first female partisan shows how political resistance was re-constituted in its very dispersal.

In addition, under the concrete condition of forced migration, new political ideas were elaborated, let us remember the creation of the Ventotene Manifesto. If, today, Europe closes its borders, it destroys the very idea behind such a vision of unification. Therefore, it is necessary not only to recall the genesis of this manifesto, but also its authors' experience of flight and being refugees.

113 Ursula Hirschmann, Noi senzapatria (Bologna 1993) 21. Translation by the author. This text was first published in 1961.

114 Luisa Passerini, 'Women in Europe, women in love. Searching for new forms of subjectivity. Third Ursula Hirschmann annual lecture on gender and Europe', (2005), http://cadmus.eui.eu/bitstream/handle/1814/8063/RSCAS_DL_2005_UHL_Passerini .pdf? sequence $=1 \&$ isAllowed $=y(23 \cdot 5 \cdot 2017)$.

115 See for example Fran Lisa Buntman, Robben Island and prisoner resistance to apartheid (Cambridge 2003). 


\section{Acknowledgement}

I would like to thank two anonymous reviewers and the participants of the conference 'Borders and Beyond: Reinventing Europe' at the Istituto Svizzero in Rome for their precious questions and comments. My special thanks for their help in drafting this paper go to Marcel Falk, Ben Jennings, Chad Jorgenson, Paola Höchner-Gallicani, Martin Mühlheim, Patricia Purtschert and Bernhard C. Schär as well as to my interview partners Enrica Canepa, Adele Conte, Silverio Lamonica, Assunta Scarpati and Vilma Lanfranconi Vitiello. 